\title{
Inhibition of attachment of oral bacteria to immortalized human gingival fibroblasts (HGF-1) by tea extracts and tea components
}

Yi Wang, Felicia FL Chung, Sui M Lee and Gary A Dykes

\begin{abstract}
Background: Tea has been suggested to promote oral health by inhibiting bacterial attachment to the oral cavity. Most studies have focused on prevention of bacterial attachment to hard surfaces such as enamel.

Findings: This study investigated the effect of five commercial tea (green, oolong, black, pu-erh and chrysanthemum) extracts and tea components (epigallocatechin gallate and gallic acid) on the attachment of five oral pathogens (Streptococcus mutans ATCC 25175, Streptococcus mutans ATCC 35668, Streptococcus mitis ATCC 49456, Streptococcus salivarius ATCC 13419 and Actinomyces naes/undii ATCC 51655) to the HGF-1 gingival cell line. Extracts of two of the teas (pu-erh and chrysanthemum) significantly $(p<0.05)$ reduced attachment of all the Streptococcus strains by up to 4 log CFU/well but effects of other teas and components were small.

Conclusions: Pu-erh and chrysanthemum tea may have the potential to reduce attachment of oral pathogens to gingival tissue and improve the health of oral soft tissues.
\end{abstract}

Keywords: Tea, Oral bacteria, Attachment, Gingival cells, Pu-erh, Chrysanthemum

\section{Findings}

\section{Introduction}

Oral Streptococci such as Streptococcus mutans are pathogens commonly associated with dental plaque and the formation of caries [1]. In order to initiate disease these bacteria must attach to components of the oral cavity such as the enamel, tongue, saliva or gums [2].

Plant extracts and phytochemicals can inhibit bacterial attachment to abiotic and biotic surfaces by altering cell surface properties including hydrophobicity, surface charge and the presence of structures such as flagella [3-5]. Tea is one such potential attachment inhibitor [6]. Nonfermented teas or partially-fermented teas, such as green tea and oolong tea, have strong bactericidal activity and may inhibit bacterial attachment to some elements of the gastrointestinal tract [7-11]. Fully fermented teas, such as black tea and pu-erh tea, have less effective bactericidal activity but may inhibit attachment of bacteria to dental plaque [12].

\footnotetext{
* Correspondence: gary.dykes@monash.edu

School of Science, Monash University, Jalan Lagoon Selatan, Bandar Sunway, 46150, Selangor, Malaysia
}

(c) 2013 Wang et al.; licensee BioMed Central Ltd. This is an Open Access article distributed under the terms of the Creative Commons Attribution License (http://creativecommons.org/licenses/by/2.0), which permits unrestricted use, distribution, and reproduction in any medium, provided the original work is properly cited.
Previous studies investigating bacterial attachment and inhibition by phytochemicals to components of the oral cavity have focused on attachment to hard surfaces such as enamel $[10,13,14]$. Attachment of bacteria to soft tissues in the mouth can also initiate disease and for this reason we investigated the effects of tea extracts and tea components on attachment of oral pathogenic bacteria to an immortalized line of connective gingival fibroblasts in vitro.

\section{Materials and methods}

\section{Bacteria and growth conditions}

Five strains of bacteria, namely Streptococcus mutans (ATCC 25175), Streptococcus mutans (ATCC 35668), Streptococcus mitis (ATCC 49456), Streptococcus salivarius (ATCC 13419) and Actinomyces naeslundii (ATCC 51655), were selected for this study and obtained from the American Type Culture Collection (Manassas, USA). All bacteria were maintained on Mitis Salivarius Agar (MSA; Difco, USA) at $4^{\circ} \mathrm{C}$ and grown in Tryptic Soy Broth (TSB; Merck, USA) at $37^{\circ} \mathrm{C}$ for $24 \mathrm{~h}$ with shaking at $150 \mathrm{rpm}$ for all experiments. Bacterial suspensions were prepared by centrifuging $20 \mathrm{~mL}$ of TSB cultures at $7669 \times \mathrm{g}$ and $4^{\circ} \mathrm{C}$ for $15 \mathrm{~min}$, washing the resultant pellet gently with 
phosphate buffered saline (PBS; $2.7 \mathrm{mM} \mathrm{KCl,} 10 \mathrm{mM}$ $\mathrm{Na}_{2} \mathrm{HPO}_{4}, 17 \mathrm{mM} \mathrm{KH} \mathrm{PO}_{4}, 137 \mathrm{mM} \mathrm{NaCl}, \mathrm{pH} 7.4 ; 1$ st BASE, Singapore) and resuspending it in $20 \mathrm{~mL}$ PBS, tea extract solutions or tea component solutions prepared as described below.

\section{Preparation of tea extracts and tea components}

Commercial green tea, oolong tea, black tea, pu-erh tea and chrysanthemum tea (Ten Ren Tea Co. Ltd., Taiwan) extracts were prepared using 90\% acetone (Sigma Aldrich, USA) at the ratio of 1:20 (wt/vol) for $2 \mathrm{~h}$. The resultant extracts were evaporated under vacuum at $40^{\circ} \mathrm{C}$, freeze dried and stored at $-20^{\circ} \mathrm{C}$ until further use. Using this method reportedly allows for extraction of more than $95 \%$ of the phenolic compounds in tea, including catechins, myricetin, quercetin and kaempherol [15]. Epigallocatechin gallate (EGCg; 95\% [vt/vt]; Sigma-Aldrich) and gallic acid (Sigma-Aldrich) were also used as they are major phenolic components of teas. Specifically, EGCg constitutes approximately $10 \%$ of the dry weight of green tea and its level decreases with increasing degree of fermentation [16]. Levels of gallic acid, on the other hand, increase with fermentation and constitute approximately $0.5 \%$ dry weight of black tea [17]. The stock solutions for all experiments were prepared by dissolving $100 \mathrm{mg}$ of tea extracts or tea component in $10 \mathrm{~mL}$ PBS containing 1\% (vol/vol) methanol (Systerm, UK) and the resultant solutions were filter sterilized though a $0.2 \mu \mathrm{m}$ filter (Millipore, USA).

\section{Determination of total phenolic, total tannin and total flavonoid content}

Total phenolic and total tannin contents of the tea extracts were determined using the Folin-Ciocalteau colorimetric method [18]. To determine the total phenolic content, a $15 \mu \mathrm{L}$ tea extract solution $(1 \mathrm{mg} / \mathrm{mL})$ was added to $80 \mu \mathrm{L}$ of $7.5 \%$ (wt/vol) sodium carbonate (R\&M Chemicals, Malaysia) and $75 \mu \mathrm{L}$ of $10 \%$ (vol/vol) FolinCiocalteau reagent ( $\&$ M Chemicals) in a well of a microtitre plate (Jet Biofil, China). The plate was incubated in the dark for $30 \mathrm{~min}$ before measuring the absorbance at $765 \mathrm{~nm}$. To determine the total tannin content, $0.5 \mathrm{~mL}$ of the sample solution was mixed with $0.5 \mathrm{~mL}$ of distilled water and $50 \mathrm{mg}$ of poly(vinylpolypyrrolidone) (PVPP; Sigma-Aldrich) which has a high affinity to tannins. The mixture was vortexed, incubated at $4^{\circ} \mathrm{C}$ for $15 \mathrm{~min}$ and vortexed again prior to centrifuging at $1409 \mathrm{~g}$ for $10 \mathrm{~min}$ in order to remove tannins. The supernatant containing non-tannin phenolics was then quantified using the Folin-Ciocalteau method described above. The difference between the total phenolic content and the non-tannin phenolic content is the measure of tannins. A standard curve was plotted using gallic acid, and the total phenolic and total tannin contents were expressed as $\mu \mathrm{g}$ gallic acid equivalent (GAE) / mg.
Total flavonoid content was measured using the aluminum chloride colorimetric method [19]. A $50 \mu \mathrm{L}$ of tea extract sample dissolved in methanol $(1 \mathrm{mg} / \mathrm{mL})$ was added to $10 \mu \mathrm{L}$ of $10 \%$ (wt/vol) aluminum chloride (Bendosen, Malaysia), $10 \mu \mathrm{L}$ of $1 \mathrm{M}$ potassium acetate (R\&M Chemicals) and $80 \mu \mathrm{L}$ of distilled water in the wells of a microtitre plate. The plate was incubated at room temperature for $30 \mathrm{~min}$ before the absorbance was measured at $435 \mathrm{~nm}$. The blank was prepared using distilled water in place of aluminum chloride. A standard curve was plotted using quercetin (Sigma-Aldrich) and the total flavonoid content was expressed as $\mu \mathrm{g}$ quercetin equivalent $(\mathrm{QE}) / \mathrm{mg}$.

\section{Cell culture}

Immortalized human gingival fibroblast-1 HGF-1 (ATCC CRL-2014) were obtained from the American Type Culture Collection and cultured in high glucose Dulbecco's modified Eagle's medium (DMEM; Sigma-Aldrich) supplemented with $4 \mathrm{mM}$ L-glutamine (Sigma-Aldrich) and $10 \%$ (vol/vol) heat-inactivated fetal bovine serum (FBS; Sigma-Aldrich). No antibiotic supplement was used. Cells were incubated at $37^{\circ} \mathrm{C}$ in $5 \% \mathrm{CO}_{2}$ atmosphere, fed every $48 \mathrm{~h}$ and routinely sub-cultured every 5 days with a split ratio of $1: 3$ using $1 \times$ trypsin-EDTA (0.05\%; Sigma-Aldrich) for $3 \mathrm{~min}$ at $37^{\circ} \mathrm{C}$.

\section{Bacterial attachment assay}

Bacterial attachment assays were as described by Mellor, Goulter, Chia, and Dykes [20] with some modifications. Briefly, monolayers of HGF-1 cells were grown in 24well tissue culture plates (Jet Biofil) to a density of 1.8 $( \pm 0.2) \times 10^{5}$ cells per well (approximately $100 \%$ coverage). Prior to the attachment assay the culture medium in each well was removed and the cell monolayer was washed with PBS. The monolayer was incubated at $37^{\circ} \mathrm{C}$ for $30 \mathrm{~min}$ with $2 \mathrm{~mL}$ aliquots of tea extracts or tea components (PBS as control) containing suspended bacteria $\left(\sim 1 \times 10^{7} \mathrm{CFU} / \mathrm{mL}\right)$. The concentrations of the tea extracts and compounds used to suspend bacteria were previously determined by antimicrobial susceptibility assays and cytotoxicity assays not kill or inhibit the bacteria or the HGF-1 cells at the concentrations used in this study. After incubation the supernatant in each well was removed and the wells were washed three times with $2 \mathrm{~mL}$ PBS. The monolayer with bacteria attached was then detached by incubating with $400 \mu \mathrm{L} 0.3 \times$ trypsin-EDTA (at which concentration trypsin does not kill or inhibit the bacteria) at $37^{\circ} \mathrm{C}$ for $5 \mathrm{~min}$. The detached bacteria were then serial diluted, spread plated on Tryptic Soy Agar (TSA; Merck) and quantified after $24 \mathrm{~h}$ incubation. The ability of bacteria to attach to wells without HGF-1 cells was also determined in order to ensure that the bacteria attached to HGF-1 cells but not to 
the plastic material of the plate. The numbers of bacteria attached to the cell line was expressed as log CFU/well.

\section{Statistical analysis}

A one way ANOVA (Tukey's comparison) was performed on all data sets using MINITAB software (MINITAB 15.1; Minitab Inc., USA) at a 95\% confidence level. All assays were performed in triplicate with independently grown cultures.

\section{Results and discussion}

The results of total phenolic, total tannin and total flavonoid content assays are presented in Table 1 . The total phenolic and total flavonoid content decreased and total tannins increased, with an increasing degree of fermentation from green tea to oolong tea to black tea to pu-erh tea. These differences between teas are probably due to the polymerization of flavonoids (especially flavon-3-ols) into large molecule polyphenols (tannins) which occur during the fermentation process [16]. Chrysanthemum tea, which is a blend of black tea and dried chrysanthemum, had similar levels of total phenolic and total tannin to pu-erh tea and similar levels of flavonoids to green tea. This suggests that dried chrysanthemum is rich in flavonoids.

Baseline data for attachment of the bacterial strains to the cell line and empty wells are shown in Table 2. Bacterial attachment to the cell line was $\sim 2 \log$ higher $(\mathrm{p}<0.05)$ than that to the plastic in the wells indicating that $90 \%$ to $99 \%$ of bacteria were attached to the cell line and validating the assay.

The results of assays investigating the effect of the tea extracts and tea components on bacterial attachment to the cell line are presented in Figure 1. All strains exhibited a similar ability to attach to the cell line except for Streptococcus salivarius ATCC 13419 which attached in significantly lower numbers as compared to Streptococcus mitis ATCC 49456 ( $\mathrm{p}<0.05)$. Green tea extracts, oolong tea extracts and black tea extracts inhibited the attachment of Streptococcus mitis ATCC49456 by between $\sim 1$ and $\sim 2 \log$ CFU/well (90-99\% attachment inhibition; $\mathrm{p}<0.05)$, but had no effect on the other strains $(\mathrm{p}>0.05)$. Pu-erh tea extracts and chrysanthemum tea extracts, on the other hand, reduced the attachment of all Streptococcus strains to cells by between $\sim 2$ and $\sim 4 \log$ CFU/well (99-99.99\% attachment inhibition; $\mathrm{p}<0.05$ ). The attachment of Actinomyces naeslundii ATCC 51665 to cells was not affected by any of the tea extracts tested ( $p>0.05)$. Of particular note is that the extract of chrysanthemum tea, which, as mentioned above, is a blend of black tea and dried chrysanthemum, had a greater $(\mathrm{p}<0.05)$ effect on inhibiting attachment than the black tea extract alone. This suggests that the active compounds in the chrysanthemum tea extract were contributed by the chrysanthemum components and not the black tea components of the mix. Pu-erh tea and chrysanthemum tea extracts, which were found to contain relatively higher levels of tannin, had a greater effect $(p<0.05)$ than the non-fermented or partially-fermented tea extracts on Streptococcus strains, suggesting that Streptococci may be more sensitive to polymeric flavonoids or other large molecule polyphenols with respect to their attachment to HGF-1.

Non-fermented or partially-fermented teas, such as green tea and oolong tea, have been previously shown to inhibit the attachment of Streptococcus mutans to collagen and tooth surfaces [12]. As indicated, in our study extracts of these teas only slightly inhibited the attachment of one bacterial strain to the gingival cell line. In addition, EGCg and gallic acid were found to have no significant effect $(p>0.05)$ on the ability of all strains to attach to the cell line. This finding suggests a possible reason for the relative ineffectiveness of the lower degree fermented tea extracts (green tea and oolong tea), which are rich in these compounds, in inhibiting adhesion. Fibronectin (Fn) is located on the outer surface of the HGF-1 plasma membrane and acts as a receptor protein for oral bacteria such as Treponema denticola [21]. Streptococcus mutans and Streptococcus salivarius have wall-associated protein A (wapA) in their outer membrane that allows them to bind collagen and a wide range of extracellular matrix molecules including type I collagen, laminin, keratin and Fn [22,23]. Tea catechins,

Table 1 Total phenolic, total tannin and total flavonoid contents of the tea extracts

\begin{tabular}{cccc}
\hline & $\begin{array}{c}\text { Total phenolic content } \\
(\boldsymbol{\mu g} \text { GAE / mg) }\end{array}$ & $\begin{array}{c}\text { Total tannin content } \\
(\boldsymbol{\mu g ~ G A E ~ / ~ m g )}\end{array}$ & $\begin{array}{c}\text { Total flavonoid content } \\
(\boldsymbol{\mu g} \text { QE / mg) }\end{array}$ \\
\hline Green tea & $527 \pm 34(\mathrm{a})$ & $149 \pm 26(\mathrm{a})$ & $7.30 \pm 0.68(\mathrm{a})$ \\
Oolong tea & $469 \pm 28(\mathrm{a}, \mathrm{b})$ & $161 \pm 35(\mathrm{a}, \mathrm{b})$ & $4.89 \pm 0.14(\mathrm{~b})$ \\
Black tea & $411 \pm 20(\mathrm{~b}, \mathrm{c})$ & $241 \pm 19$ (b, c) & $2.97 \pm 0.59(\mathrm{c})$ \\
Pu-erh tea & $349 \pm 35(\mathrm{c})$ & $305 \pm 34$ (c) & $1.68 \pm 0.68(\mathrm{c})$ \\
Chrysanthemum tea & $376 \pm 13$ (c) & $280 \pm 8$ (c) & $7.61 \pm 0.42(\mathrm{a})$ \\
\hline
\end{tabular}

All results are presented as the means followed by SDs. Values labeled with the same letter are not significantly different ( $p>0.05)$ among the tea extract samples. Tukey's comparisons were conducted separately for each assay. 
Table 2 Baseline data for bacterial attachment to the HGF-1 cell line and empty wells

\begin{tabular}{cccccc}
\hline & \multicolumn{5}{c}{ Mean \pm SD attachment (log CFU/well) } \\
\cline { 2 - 6 } & $\begin{array}{c}\text { Streptococcus mutans } \\
\text { ATCC25175 }\end{array}$ & $\begin{array}{c}\text { Streptococcus mutans } \\
\text { ATCC35668 }\end{array}$ & $\begin{array}{c}\text { Streptococcus salivarius } \\
\text { ATCC13419 }\end{array}$ & $\begin{array}{c}\text { Streptococcus mitis } \\
\text { ATCC49456 }\end{array}$ & $\begin{array}{c}\text { Actinomyces naeslundii } \\
\text { ATCC51655 }\end{array}$ \\
\hline Attachment to cell line & $4.67 \pm 0.25$ & $4.75 \pm 0.35$ & $3.68 \pm 0.77$ & $5.11 \pm 0.14$ & $4.68 \pm 0.34$ \\
Attachment to empty & $2.37 \pm 0.18$ & $2.38 \pm 0.27$ & $2.14 \pm 0.49$ & $2.34 \pm 0.47$ & $2.19 \pm 0.08$ \\
wells & & & & \\
\hline
\end{tabular}

such as EGCg, have been reported to impair the adhesion promoting ability of Fn [24], and inhibit the interactions between Fn and attaching cells by binding to the Fn receptor integrin $\beta 1$ [25]. These catechins should theoretically inhibit attachment but this was not the case in our study.

This study suggests that the mechanisms of inhibition of attachment of oral pathogens to gingival cells by tea or tea extracts may be different than that of inhibition to other components of the oral cavity. Based on this in vitro study extracts of pu-erh tea and chrysanthemum tea, in particular, may have the potential to reduce attachment of oral pathogens to gingival tissue and improve the health of oral soft tissues but this finding needs to be confirmed by in vivo studies. In order to further assess the situation in the oral cavity testing fresh brewed teas (hot water extracts) for adhesion inhibitory effect is required. The experimental setup used in this study could also be used to evaluate the effect of tea on the adhesion of other oral pathogenic microorganism, such as Candida albicans, which have been reported to adhere to human buccal epithelial cells and cause oral candidosis [26].
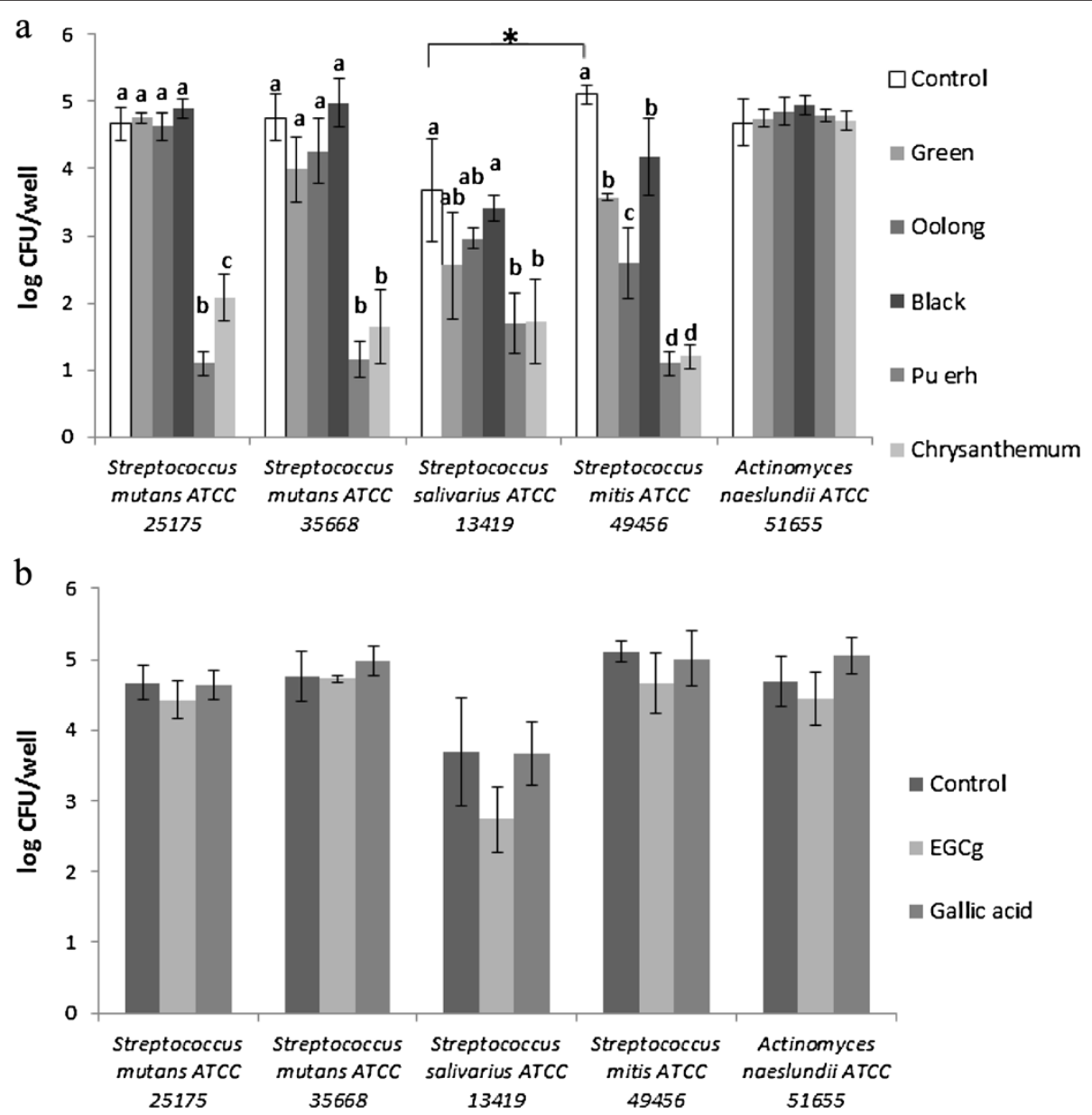

Figure 1 Effects of extracts and compounds on oral bacterial attachment. Effect of tea extracts (a) and EGCg and gallic acid (b) on oral bacterial attachment to the HGF-1 gingival cell line (log CFU/ $\mathrm{cm}^{2}, \mathrm{n}=3$ ). Values labeled with the same letter are not significantly different ( $p>0.05)$ among the treatments within a strain. Tukey's comparisons were conducted separately for each strain. The * symbol indicates that the attachment of Streptococcus salivarius was significantly different from that of Streptococcus mitis $(p<0.05)$. 


\section{Abbreviations}

HGF-1: Human gingival fibroblast-1; CFU: Colony forming unit;

ATCC: American type culture collection; PBS: Phosphate buffered saline; EGCg: Epigallocatechin gallate; TSA: Tryptic soy agar; TSB: Tryptic soy broth; PVPP: Poly(vinylpolypyrrolidone); GAE: Gallic acid equivalent; QE: Quercetin equivalent; DMEM: Dulbecco's modified Eagle's medium; FBS: Fetal bovine serum; ANOVA: Analysis of variance; Fn: Fibronectin; WapA: Wall-associated protein A; SD: Standard deviation.

\section{Competing interests}

The authors declare that they have no competing interests.

\section{Authors' contributions}

YW carried out the cell culture, attachment study, statistical analysis and drafted the manuscript. FFLC participated in the cell culture and reviewed the manuscript. SML reviewed and revised the manuscript for intellectual content. GAD contributed to the conception and design of the study and reviewed and revised the manuscript. All authors read and approved the final manuscript.

\section{Acknowledgement}

The authors acknowledge financial support for this study from Monash University, Malaysia.

Received: 11 November 2012 Accepted: 3 April 2013

Published: 11 April 2013

\section{References}

1. Hamilton-Miller J: Anti-cariogenic properties of tea (Camellia sinensis). $J$ Med Microbiol 2001, 50(4):299-302.

2. Kolenbrander PE, London J: Adhere today, here tomorrow: oral bacterial adherence. J Bacteriol 1993, 175(11):3247-3252.

3. Goulter RM, Gentle I, Dykes GA: Issues in determining factors influencing bacterial attachment: a review using the attachment of Escherichia coli to abiotic surfaces as an example. Lett Appl Microbiol 2009, 49(1):1-7.

4. Nostro A, Cannatelli M, Crisafi G, Musolino A, Procopio F, Alonzo V: Modifications of hydrophobicity, in vitro adherence and cellular aggregation of Streptococcus mutans by Helichrysum italicum extract. Lett Appl Microbiol 2004, 38(5):423-427.

5. Sklodowska A, Matlakowska R: Relative surface charge, hydrophobicity of bacterial cells and their affinity to substrate during copper bioleaching from post-flotation wastes. Biotechnol Lett 1998, 20(3):229-233.

6. Tagashira M, Uchiyama K, Yoshimura T, Shirota M, Uemitsu N: Inhibition by hop bract polyphenols of cellular adherence and water-insoluble glucan synthesis of mutans streptococci. Biosci Biotech Bioch 1997, 61(2):332-335.

7. Lee JH, Shim JS, Lee JS, Kim JK, Yang IS, Chung MS, Kim KH: Inhibition of pathogenic bacterial adhesion by acidic polysaccharide from green tea (Camellia sinensis). J Agric Food Chem 2006, 54(23):8717-8723.

8. Otake S, Makimura M, Kuroki T, Nishihara Y, Hirasawa M: Anticaries effects of polyphenolic compounds from Japanese green tea. Caries Res 1991, 25(6):438-443.

9. Rasheed A, Haider M: Antibacterial activity of Camellia sinensis extracts against dental caries. Arch Pharm Res 1998, 21(3):348-352.

10. $X u X, Z$ hou $X D$, Wu CD: The tea catechin epigallocatechin gallate suppresses cariogenic virulence factors of Streptococcus mutans. Antimicrob Agents Chemother 2011, 55(3):1229-1236.

11. Yoshino $K$, Nakamura $Y$, Ikeya $H$, Sei $T$, Inoue A, Sano M, Tomita I: Antimicrobial activity of tea extracts on cariogenic bacterium (Streptococcus mutans). J Food Hyg Soc Japan 1996, 37(2):104-108.

12. Friedman M: Overview of antibacterial, antitoxin, antiviral, and antifungal activities of tea flavonoids and teas. Mol Nutr Food Res 2007, 51(1):116-134

13. Abbott A, Rutter $P$, Berkeley $R$ : The influence of ionic strength, $\mathrm{pH}$ and a protein layer on the interaction between Streptococcus mutans and glass surfaces. J Gen Microbio/ 1983, 129(2):439-445.

14. Clark W, Gibbons R: Influence of salivary components and extracellular polysaccharide synthesis from sucrose on the attachment of Streptococcus mutans 6715 to hydroxyapatite surfaces. Infect Immun 1977 18(2):514-523.

15. Perva-Uzunalic A, Skerget M, Knez Z, Weinreich B, Otto F, Gruner S: Extraction of active ingredients from green tea (Camellia sinensis):
Extraction efficiency of major catechins and caffeine. Food Chem 2006 96(4):597-605

16. Peterson J, Dwyer J, Bhagwat S, Haytowitz D, Holden J, Eldridge AL, Beecher G, Aladesanmi J: Major flavonoids in dry tea. J Food Compos Anal 2005, 18(6):487-501

17. Cabrera C, Gimenez R, Lopez MC: Determination of tea components with antioxidant activity. J Agric Food Chem 2003, 51(15):4427-4435.

18. Megat Rusydi MR, Azrina A: Effect of germination on total phenolic, tannin and phytic acid contents in soy bean and peanut. Int Food Res $J$ 2012, 19(2):673-677

19. Chang CC, Yang MH, Wen HM, Chern JC: Estimation of total flavonoid content in propolis by two complementary colorimetric methods. J Food Drug Anal 2002, 10(3):178-182.

20. Mellor GE, Goulter RM, Chia TWR, Dykes GA: Comparative analysis of attachment of Shiga-toxigenic Escherichia coli and Salmonella strains to cultured HT-29 and Caco-2 cell lines. Appl Environ Microbiol 2009, 75(6):1796-1799.

21. Ellen RP, Song M, McCulloch C: Degradation of endogenous plasma membrane fibronectin concomitant with Treponema denticola 35405 adhesion to gingival fibroblasts. Infect Immun 1994, 62(7):3033-3037.

22. Han TK, Zhang C, Dao ML: Identification and characterization of collagenbinding activity in Streptococcus mutans wall-associated protein: a possible implication in dental root caries and endocarditis. Biochem Biophys Res Commun 2006, 343(3):787-792.

23. Weerkamp AH, Jacobs T: Cell wall-associated protein antigens of Streptococcus salivarius: purification, properties, and function in adherence. Infect Immun 1982, 38(1):233-242.

24. Ogata K, Mukae N, Suzuki Y, Satoh K, Narumi K, Nukiwa T, Isemura M: Effects of catechins on the mouse tumor cell adhesion to fibronectin Planta Med 1995, 61(5):472-474.

25. Suzuki Y, Suzuki T, Minami T, Isemura M: Involvement of impaired interaction with $\beta 1$ integrin in epigallocatechin gallate-mediated inhibition of fibrosarcoma HT-1080 cell adhesion to fibronectin. J Health Sci 2006, 52(2):103-109.

26. Ellepola AN, Samaranayake LP: Adhesion of oral C. albicans to human buccal epithelial cells following limited exposure to antifungal agents. J Oral Pathol Med 1998, 27(7):325-332

doi:10.1186/1756-0500-6-143

Cite this article as: Wang et al:: Inhibition of attachment of oral bacteria to immortalized human gingival fibroblasts (HGF-1) by tea extracts and tea components. BMC Research Notes 2013 6:143.

\section{Submit your next manuscript to BioMed Central and take full advantage of:}

- Convenient online submission

- Thorough peer review

- No space constraints or color figure charges

- Immediate publication on acceptance

- Inclusion in PubMed, CAS, Scopus and Google Scholar

- Research which is freely available for redistribution 